\title{
Chincse Americans and the Borderland Experience on Golden Mountain: The Development of a Chinese American Identity in The Woman Warrior: Memoirs of a Girlhood Among Ghosts
}

\section{Diane Todd Bucci Robert Morris University}

In The Woman Warrior: Memoirs of a Girlhood Among Ghosts, Maxine Hong Kingston tells the story of her immigrant family and their efforts to rise above their workingclass status in America, which optimistic Chinese regard as the Golden Mountain. The Hongs' experience is not unlike that of other immigrants who come to America to escape hardship in their homeland and hope to live the American Dream. The road to American success has numerous obstacles, and immigrants encounter many conflicts on their joumey. One conflict relates to their cultural identities. Gloria Anzaldúa uses the word "borderland" to refer to the meeting of two cultures, and she defines the borderland as a "place of contradictions. Hatred, anger and exploitation are the prominent features of this landscape" (n.p.). While Anzaldúa's discussion focuses on the borderland encountered by Mexican Americans, she believes that many share this painful experience:

The psychological borderlands, the sexual borderlands and the spiritual borderlands are not particular to the Southwest. In fact the borderlands are physically present wherever two or more cultures edge each other, where people of different races occupy the same temitory, where under, lower, middle and upper classes touch, where the space between two individuals shrinks with intimacy. (n.p.)

The most obvious borderland that immigrants face is when they come in contact with the new culture, but they also encounter discord within their own culture as they become Americanized. The conflict with the mother culture is exacerbated for the children of immigrants who are, most likely, more Americanized than their parents. As E. D. Huntley points out, "Complicating identity is the condition of biculturalism, a double existence that produces in the descendant of immigrants the feeling of belonging to two distinct cultural traditions, yet not feeling completely comfortable in either one" (106). Thus, an often unacknowledged aspect of American success is overcoming the identity crisis that many experience as they attempt to find a balance between their ethnic and American identities. As well, women of color are doubly marginalized because of their ethnicity and gender, so ethnic women often encounter dual bariers on the path to upward mobility.

Kingston's memoir explores the Hong' achievement of the American Dream and the borderland experience of their second-generation daughter as she attempts to unite her 
Chinese and American identities. As Sau-Ling Cynthia Wong reminds us, ' $I$ t is, in fact, essential to recognize that the entire Woman Warior is a sort of mediation on what it means to be Chinese American" (160). Because the work is labeled an autobiography, many readers refer to the narrator as Maxine; however, Kingston explicitly states, "Her name isn't Maxine; that's my name" (Skenazy 133). Kingston goes on to explain that her failure to name the narrator is very deliberate because "she's still trying to find out who she is" (Skenazy 133). Thus, being unnamed is symbolic of the identity crisis that the narrator suffers because she is bicultural. Huntley notes that her "childhood and young adult years are marked by tremendous dislocation, the result of growing up between the Old World (China) and the New (the United States), of growing up "hyphenated"' (106). As they straddle the two cultures, it is not uncommon for some Chinese Americans to feel like outsiders in both: they encounter racism and oppression within the Anglo culture because of their Chinese characteristics, and they also face conflicts within their mother culture because they are Americanized. The identity crisis that the narrator experiences is worsened by the fact that she is a female in a culture that does not value women. Ultimately, the work is a story of American success, though not because of the narrator's eventual financial security, which is how Americans typically define success, but because she finally accepts her dual heritage and develops a Chinese American voice that she uses to empower herself as well as the women of both cultures.

The Hongs' beginnings in America were typical of many immigrants who came to her shores longing for a better life. Kingston describes her father and his male relatives who left their homeland in 1924, hoping to find monetary relief in America: the "men - hungry, greedy, tired of planting dry soil had been forced to leave the village in order to send foodmoney home" (13). Like other immigrants, they discoverod that the Golden Mountain's offerings were, in fact, meager: the only employment that they could find was low-paying, back-breaking work as laborers. Some of them earned enough money to support their families who remained in China, and eventually, they sent for their wives and children to join them.

The establishment of their own uniquely ethnic communities provides immigrants with a feeling of comfort in a country where all is unfamiliar, thus, like other immigrant groups, when Chinese families settled in America, they established communities with those who were also from their homeland, hence the development of America's Chinatowns. The Hongs moved to the Stockton, Califomia Chinatown, and they "settled among immigrants who had also been their neighbors in the ancestral land" (15-16) because "[l]giving among one's own emigrant villagers can give a good Chinese far from China glory and a place" (52). Jack Chen explains that their ethnic community served as a "unifying factor" for the Chinese (19); as a result, Chinatown "was invaluable in giving them confidence to deal with the very considerable pressures of the langer society, which were often extremely severe. The immigrants needed all the support they could get to withstand them" (Chen 62). Thus, Chinatown gives the Hongs a sense of security in what is initially a foreign land. 
Although they live in a Chinese community, the Hongs, like other immigrants, are drawn to the American Dream, and by working hard, the family achieves the building blocks of the Dream. For example, they become small business owners by opening a laundry, and the Hongs' hard work grants them financial rewards. They are able to purchase goods which signify that they are upwardly mobile, and the Hongs' apartment gradually transforms itself: "I watched our parents buy a sofa, then a rug, curtains, chairs to replace the orange and apple crates one by one, now to be used for storage," and eventually, they purchase a car (191), says the narrator. Their financial success also enables the family to partake in American frivolities: they fly kites and go to camivals and American movies. Although the Hongs enjoy the illusion of modest success, white America still identifies them as foreigners.

Despite and perhaps because of their apparent accomplishments, Chinese are often the victims of American racism. Because of their physical differences, it is impossible for the Chinese to assimilate completely. Sucheng Chan observes, "Even if an Asian person is willing to change names, his or her physical features are still unassimilated. .. [P]eople of color cannot 'pass' in white America through a simple name change" (35). The narrator hopes to blend in at school by making herself American-feminine. She recalls trying to walk "crect (knees straight, toes pointed forward, not pigeon-toed, which is Chinese-feminine)" (11). Similarly, her friends are unhappy with their Asian features and try to Anglicize themselves by taping their eyelids (182), but their appearance acts as a barier to American acceptance because it identifies them as foreigners in the eyes of the Anglos. It is not surprising that young Chinese Americans develop feelings of self-loathing that distance them from their Chinese identities.

Not only does their physical appearance cause them to stand out, but the namator explains that the Chinese manner of speaking isolates them as well. She explains that Chinese immigrants talk loudly and find it difficult to adapt their speech so that they sound American: "The immigrants I know have loud voices, unmodulated to American tones even after years away from the village where they called their friendships out across the fields" (11). Americans are repulsed by the Chinese sounds: "You can see the disgust on American faces looking at women like that. It isn't just the loudness. It is the way Chinese sounds, chingchong ugly, to American cars" (171). In the family laundry, they humiliate the narrator by making fun of her Chinese accent: "'No tickee, no washee, mama-san' a ghost [an Anglo] would say, so embarrassing" (105). Just as she and her friends attempt to modify their looks, they try to alter their way of speaking as well: "We American-Chinese girls had to whisper to make ourselves American-feminine" (172). Despite their attempts to Anglicize themselves, the girls feel like foreigners in Anglo schools. Chan believes that the primary goal of American schools

was to inculcate Anglo-American values, behavioral pattems, and speech pattems. Students who spoke pidgin English at home and in the playgrounds had to master standard English if they wished to pursue higher education. 


\section{Ethnic Studies Review Volume 30: 1\&2}

The message they received everywhere was that their own origins were inferior and their people powerless. Only by "Americanizing" could they hope for a better life. (59)

Because they are made to feel inferior, it is inevitable that the children fear American schools. The narrator recalls, "When I went to kindergarten and had to speak English for the first time, I becarne silent. ... During the first silent year I spoke to no one at school, did not ask before going to the lavatory, and flunked kindergarten" (165). The narrator's difficulty speaking may be attributed to the American teachers' inability to account for her cultural differcnces. When she finally speaks in 'the barest whisper" in first grade, the white teacher "scared the voice away again" by demanding that she speak louder (168). Rather than helping the narrator overcome her differences, the teacher reacts by placing her near a group of noisy boys, thus suggesting that the child is unworthy of her attention. A Hawaiian teacher, who should, in theory, be more attuned to cultural differences, excludes the Chinese girls from participating in a class play because their "voices were too soft or nonexistent" (167). For the nanator, attending American schools is painful because the dominant white culture is unwilling to accept her cultural diffenences, and this further alienates her from her ethnic identity.

When the narrator meets another Chinese girl who also refuses to speak, she sees a mirror image of herself and hates the girl for reminding her of her own silence. She attempts to force the girl to talk because she understands that, like herself, the girl cannot be an American success without an American voice. In her discussion of Chang-rae Lee's novel Native Speaker, June Dwyer makes several points that are pertinent to understanding the narrator's feelings about silence. Dwyer writes:

Immigrants want to learn English because they know their chances of more than modest success in this country are virtually nil without it. But the practical element constitutes only part of the immigrant desire to master English. The other component is psychological; not to speak English is to be ignored.... The fact that silence is tantamount to invisibility both disturbs and undermines the confidence of the immigrant. (73-74)

When the narrator tells the silent girl, "You've got to let people know you have a personality and a brain" (180), she shows that she recognizes that as woinen and as non-native speakers of English, Chinese women risk being doubly marginalized. The silent girl helps the narrator to recognize the limitations that are placed on Chinese American women as a result of their sexual and cultural differences. This awareness enables the narrator to develop an Americanized voice, and she uses her new voice to rebel against her parents and their Old World ways: 
I'm going to college. And I'm not going to Chinese school anymore. I'm going to run for office at American school, and I'm going to join clubs. I'm going to get enough offices and clubs on my record to get into college. And I can't stand Chinese school anyway; the kids are rowdy and mean, fighting all night. And I don't want to listen to any more of your stories; they have no logic. They scramble me up. You lie with stories. (202)

The narrator announces a break from her Chinese heritage, but she has little understanding of the culture from which she is separating.

The borderland that the Chinese American narrator experiences with her mother culture is reinforced by a dominant culture that stereotypes the Chinese as well as parents who are unwilling to discuss their cultural beliefs. The narrator notes, "Those of us in the first American generations have had to figure out how the invisible world the emigrants built around our childhoods fits in solid America" (5). She believes that the children of Chinese immigrants do not understand their culture because it is not explained to them. She wonders,

Chinese-Americans, when you try to understand what things in you are Chinese, how do you separate what is peculiar to childhood, to poverty, insanities, one family, your mother who marked your growing with stories, from what is Chinese? What is Chinese tradition and what is the movies? (56)

The confusion is further complicated by the fact that the Chinese are misrepresented in American popular culture where children are introduced to American stereotypes of the Chinese, and in American schools, the children leam little about their history. Chan explains, "Regardless of whether they attended integrated or segregated schools, children of Asian ancestry on the mainland were taught by white teachers and leamed from textbooks that contained no information about their own cultural legacy" (63). Thus, Chinese American children find few accurate explanations of their culture within the Anglo culture. Although the children may grow up hearing their mothers talk story (the Chinese tradition of storytelling) about Chinese myths, the children of Chinese immigrants are unlikely to have direct contact with China; therefore, they must rely on their parents' explanations of Chinese history and traditions. However, often the Chinese beliefs are avoided by knowledgeable family members; for example, Brave Orchid "never explained anything that was really important." The narrator complains, "[W] kids had to infer the holidays. She did not whip us up with holiday anticipation or explain" (185). As a result, the Chinese American children are further alienated from their Chinese identities. The narrator wonders, "How can Chinese keep any traditions at all? They don't even make you pay attention, slipping in a ceremony and clearing the table before the children notice specialness. The adults get mad, evasive, and shut you up if you ask" (185). Brave Orchid, however, does not discuss her culture's 


\section{Ethnic Studies Review Volume 30: 1\&2}

traditions because she considers her children to be Americans. The narrator explains, "They would not tell us children because we had been bom among ghosts, were taught by ghosts, and were ourselves ghost-like. They called us a kind of ghost' (183). Thus, parents see their children as foreigners, and the borderland created by these feelings makes it difficult for Chinese American children to feel loyal to their Chinese heritage.

Reconciling with their Chinese roots is particularly difficult for Chinese girls bocause their culture teaches that "[g]irls are maggots in the rice" (Kingston, Woman Warrior, 43). According to Chinese beliefs, women have few rights as individuals; in fact, a woman's lack of freedom is demonstrated by the culture's mariage customs. When a Chinese woman marries, she becomes the property of her in-laws: "Daughters-in-law lived with their husbands' parents, not their own; a synonym for marriage in Chinese is 'taking a daughterin-law" (Kingston, Woman Wamior, 7), which exhibits the degree to which a woman is considered to be a piece of property. However, while the Chinese convey the belief that women are useless, when the adults talk story they often share tales of heroines who are swordswomen. Diane Simmons wonders, "How has this portrait of female power cmerged, if women in Chinese culture are so thoroughly disenfranchised?" Simmons offers, "One answer may be that Chinese women have always found ways to subtly subvert their society's rules" (56). Brave Orchid serves as an excellent example of Simmons's suggestion. Brave Orchid rebels against her culture's misogynistic beliefs by intimating to her daughter that she can choose to grow up to be a strong woman. For example, while Brave Orchid tells her that she "would grow up a wife and a slave [sic]," she also teaches her about the warrior woman, Fa Mu Lan (20). Because of these contradictory lessons, the narrator recognizes that she has the power to control her own destiny and resolves, "I would have to grow up a warrior woman" (20). W. Lawrence Hogue acknowledges that the nanrator searches "for social identification and historical continuity" in these Chinese myths, but he believes that she fails to find appropriate role models (122). However, it is important to note that these myths cmpower the narrator by compelling her to write. By telling her story, the narrator nullifies her culture's view of women by talking story about how her culture subjugates women; thus, although the narrator has grown up in a misogynistic culture, she caries on her female ancestors' acts of subversion.

In addition to talking story about victimized women, the narrator revises the traditional myths so as to portray the female subjects as powerful re-creations. For example, by telling the story of "No Name Woman" in the first chapter, she illustrates the oppression that Chinese women confront within their patriarchal culture. "No Name Woman" is about her aunt, who committed suicide because she became pregnant and sharned her family. Brave Orchid tells the story as a lesson as her daughter enters womanhood: she should not humiliate her family in such a way. The narrator is told to keep the story a secret: "Don't tell anyone you had an aunt. Your father does not want to hear her name. She has never been bom" (15). By accepting these instructions, the narrator realizes, "[T]hey want me to participate in her punishment. And I have" (16). However, by finally telling the story "after 
fifty years of neglect" (16), as well as by creating altemate versions that do not portray her aunt as a victim, the narrator gives voice to her oppressed, forgotten aunt, thereby empowering No Name Woman. Similarly, "White Tigers," the second chapter, is the traditional story of Fa Mu Lan. However, according to the narrator's adaptation, Fa Mu Lan dresses as a man, assumes her father's place in battle, and becomes a heroine to her family and her village. Thomas J. Ferraro believes that the narrator "interprets Fa Mu Lan, in unprecedented fashion, as a protofeminist. Whereas the traditional story emphasizes bleak sacrifice . . . she emphasizes a desirable role transcendence" (168-69). Thus, by revising traditional Chinese myths, the nanrator empowers herself and her culture's victimized females.

In a similar fashion, the narrator contrasts the stories of Brave Orchid and her sister, Moon Orchid, to inspire women. She demonstrates that a woman has the power to choose her fate. She can be strong, like Brave Orchid, or she can be a victim, like Moon Orchid. By telling Brave Orchid's story in "Shaman," the narrator portrays her mother as a feminist role model. Before coming to America, Brave Orchid uses the money that her husband sends home to attend medical school. After graduating, she retums to her village to be a midwife. Ferraro obscrves, 'The author's recreation pays testimony to her mother's courage and power in breaking away from the village, completing her training, and reconstituting herself within a profession among similarly uprooted women" (175). As a contrast to Brave Orchid's story, in "At the Western Palace" Moon Orchid is portrayed as a passive, voiceless woman who has waited in China for thirty years for her husband to invite her to join him in America. When a reunion with him is unsuccessful, Moon Orchid's resulting insanity is a means of escaping her disappointment. The narrator uses Moon Orchid's unfortunate experience to motivate women to become self-sufficient. As a result of their aunt's broken heart, "Brave Orchid's daughters decided fiercely that they would never let men be unfaithful to them. All her children made up their minds to major in science or mathematics" (160). By talking story about Brave Orchid and Moon Orchid, the narrator illustrates that a woman, even a Chinese woman, has the power to determine her own fate.

Because she is oppressed by both the dominant culture and her own culture, it is doubly difficult for the Chinese American woman to achieve American success. For many, these marginalizations maximize their determination to succeed, both as ethnics and as women. Ronald Takaki explains that many second generation Chinese Americans "wanted to break away from the immigrant status of their parents and hoped that education and employment in the professions and skilled occupations would advance them toward equality in American society" (265). Thus, one reason that the narrator wants to go to college is to achieve more than the modest goals that her parents have set for her. Patricia Chu agrees: "A powerful subtext of this book is the narrator's desire to rise above her parents' low social status in America. Thus her declaration that she will go to college instead of marrying a Chinese immigrant or becoming a clerk-typist ... is a stinging rejection of her parents' class 
status" (101). Clearly, her parents' marginalized position and humble expectations compel the narrator to stive to obtain the American Dream of financial stability.

But perhaps a more significant reason that the narrator wants to be an American success is to convince her parents that she is as valuable as a boy, so she attempts to prove her worth by showing her intellectual abilities. The narrator excels in school, but this does not alter her position within her family. She complains, I "studied hard, got straight A's, but nobody seemed to see that I was smart" (195). The narrator believes that her mother is unimpressed by her scholastic accomplishments, and she asks,

Do you know what the Teacher Ghosts say about me? They tell me I'm smart, and I can win scholarships. I can get into colleges. I've already applied. I'm smart. I can do all kinds of things. I know how to get A's, and they say I could be a scientist or a mathematician if I want. I can make a living and take care of myself. (201)

When she is unsuccessful at gamering her family's respect, the narrator attempts to validate her identity by leaving home: "I went away to college Berkeley in the sixties and I studied, and I marched to change the world, but I did not tum into a boy. I would have liked to bring myself back as a boy for my parents to welcome with chickens and pigs" (47). Although she is on her way to becoming an American success, the nanator remains a girl in her parents' eyes and is therefore less valuable than her brothers.

Because she feels inferior in her own culture, the nanator's conflicts with her Chinese heritage persist in adulthood. She finds comfort in her American accomplishments: "When I visit the family now, I wrap my American successes around me like a private shawl; I am worthy of eating the food" (52); however, she continues to resist the part of her that is Chinese by attempting to make her "life American-normal" (87). She sees the Chinese traditions as confusing and illogical, and she prefers the ease with which she understands American ways. She confesses, "Give me plastics, periodical tables, t.v. dinners with vegetables no more complex than peas mixed with diced carrots" (204). Funthermore, she abandons the traditional responsibilities of a Chinese woman: "Even now, unless I'm happy, I burn the food when I cook. I do not feed people. I let the dirty dishes rot. I eat at other people's tables but won't invite them to mine, where the dishes are rotting" (48). The narrator illustrates that for some Chinese American women, achieving the American Dream is not simply about financial success; it is also a means of resisting the rigid gender roles imposed on them by their Chinese culture.

Despite the narrator's seeming contentment with her American accomplishments, it is impossible for her to deny the part of her that is Chinese: "Even now China wraps double binds around my feet," she says (48). Ultimately, the narrator recognizes that she must embrace her two identities. As Huntley explains, border inhabitants 
have double identities they are of both cultures and can negotiate each one separately, but their true identities are bound up with their dual heritage. Shaped by the dominant culture in which they have been educated, these individuals nonetheless feel strongly drawn to the traditions and values of their families and to their parents' ancestral cultures. (73)

The narrator's ultimate acceptance of her Chinese heritage is represented by her relationship with her mother and the Chinese tradition of talking story. She explains, "At last I saw that I too had been in the presence of great power, my mother talking-story" (19-20). This realization enables her to reconcile with her Chinese self for she recognizes that as an adult, she talks story according to the Chinese traditions. At the same time, however, her manner of talking story also demonstrates the influence of American attitudes. While she tells her mother's stories, she creates her own Americanized endings. For example, in the final chapter, "A Song for a Barbanian Reed Pipe," the narrator shares the tale of the poetess, Ts'ai Yen: "Here is a story my mother told me, not when I was young, but recently, when I told her I also talk story. The beginning is hers, the ending, mine" (206). As Hogue explains, "In telling her own story, the female narrator uses talk-storying to synthesize her Chinese and American heritages" (127). Huntley calls this union her "authentic self' and explains that it

will necessanily be neither Chinese nor mainstream American, but will incorporate elements of both into a Chinese American identity. The stuggle to create a new and more inclusive definition of the designation "American" is a theme that permeates all of Maxine Hong Kingston's work. (107)

Not sumprisingly, Kingston believes that "we ought to leave out the hyphen in 'ChineseAmerican,' because the hyphen gives the word on either side equal weight, as if linking two noums .... Without the hyphen, 'Chinese' is an adjective and 'American' a noun; a Chinese American is a type of American" ("Cultural Mis-readings" 99).

The narrator overcomes the borderland conflict and develops into a harmonious adult by accepting her biculturalism. By talking story, she shows that she has come to tems with her Chinese ancestry. By adapting the stories, she reveals her American self. As well, the narrator shows that one need not assimilate to be an American success. In reality, true success should be defined by our ability to celebrate our hybrid identities. We need to recognize that one need not be white to be accepted as an American. 


\section{Works Cited}

Anzaldúa, Gloria. Borderlands, La Frontera: The New Mestiza. San Francisco: Aunt Lute, 1987.

Chan, Sucheng. Asian Americans: An Interpretive History. Boston: 1991.

Chen, Jack. The Chinese of America. San Francisco: Harper, 1980.

Chu, Patricia. "“The Invisible World the Emigrants Built': Cultural Self-Inscription and the Antiromantic Plots of The Woman Warior." Diaspora 2.1 (1992): 95-115. Dwyer, June. "Speaking and Listening: The Immigrant as Spy Who Comes in from the Cold." Payant and Rose 73-82.

Fenraro, Thomas J. Ethnic Passage: Literary Immigrants in Twentieth-Century America. Chicago: U of Chicago P, 1993.

Hogue, W. Lawrence. Race, Modemity, Postmodemity: A Look at the History and the Literatures of People of Color Since the 1960s. Albany: State U of New York P, 1996.

Huntley, E.D. Maxine Hong Kingston: A Critical Companion. Westport: Greenwood, 2001.

Kingston, Maxine Hong. "Cultural Mis-readings by American Reviewers." Skandera-Trombley 95-103.

- . The Woman Warior: Memoirs of a Girlhood Among Ghosts. 1975. New York: Vintage, 1989.

Payant, Katherine B. and Toby Rose, eds. The Immigrant Experience in North American Literature: Carving Out a Niche. Westport: Greenwood, 1999.

Simmons, Diane. Maxine Hong Kingston. New York: Twayne, 1999.

Skandera-Trombley, Laura E., ed. Critical Essays on Maxine Hong Kingston. New York: G.K. Hall, 1998.

Skenazy, Paul. "Kingston at the University." Skenazy and Martin 118-158.

Skenazy, Paul, and Tara Martin, eds. Conversations with Maxine Hong Kingston. Jackson: UP of Mississippi, 1998.

Takaki, Ronald. Strangers from a Different Shore: A History of Asian Americans. Boston: Little, 1989.

Wong, Sau-Ling Cynthia. "Autobiography as Guided Chinatown Tour? Maxine Hong Kingston's The Woman Wanior and the Chinese-American Autobiographical Controversy." Skandera-Trombley 146-167. 